\begin{tabular}{|l|l|l||}
\hline \multicolumn{2}{|c|}{ PublisherInfo } \\
\hline \hline PublisherName & $:$ & BioMed Central \\
\hline \hline PublisherLocation & $:$ & London \\
\hline \hline PublisherImprintName & $:$ & BioMed Central \\
\hline \hline
\end{tabular}

\title{
Progesterone in mouse mammary gland carcinogenesis
}

\begin{tabular}{|c|c|c|}
\hline \multicolumn{3}{|c|}{ ArticleInfo } \\
\hline ArticleID & : & 3657 \\
\hline ArticleDOI & : & 10.1186/bcr-1999-66635 \\
\hline ArticleCitationID & : & 66635 \\
\hline ArticleSequenceNumber & : & 23 \\
\hline ArticleCategory & : & Paper Report \\
\hline ArticleFirstPage & : & 1 \\
\hline ArticleLastPage & : & 4 \\
\hline ArticleHistory & : & $\begin{array}{ll}\text { RegistrationDate } & : \text { 1999-10-22 } \\
\text { OnlineDate } & : \text { 1999-10-22 }\end{array}$ \\
\hline ArticleCopyright & : & Current Science Ltd1999 \\
\hline ArticleGrants & : & \\
\hline ArticleContext & $:$ & 1305822 \\
\hline
\end{tabular}




\section{Keywords}

carcinogenesis, mammary gland, estrogen, progesterone, progesterone receptor

\section{Introduction}

Although estrogen has long been thought of as the major ovarian mitogen involved in proliferation of normal human mammary epithelium and in neoplastic progression, there is some evidence that progesterone may play a role. In both mouse and rat mammary gland, it is apparent that progesterone is specifically involved in inducing epithelial proliferation and this has been supported by progesterone receptor knockout (PRKO) mice where development of the gland is retarded. The luminal compartment of mouse mammary epithelium has been shown to be the target of the progesterone-induced proliferative signal and is also the site of mammary epithelial tumorigenesis.

\section{Aims}

To define the functional relevance of progesterone-initiated intracellular signaling in mammary gland tumorigenesis by using the PRKO mouse model in the context of an established carcinogen-induced mammary tumorigenesis system.

\section{Comments}

These novel data demonstrate conclusively that progesterone and its receptor are vital for DMBAinduced tumorigenesis in the mouse mammary gland. However, it is not clear how relevant this is to human breast cancer etiology. The authors acknowledge that a mitogenic role of progesterone in normal and malignant human breast epithelium has not been clearly defined while the role of estrogen is widely accepted. This differs completely from the mouse where the mitogenic action of progesterone in alveolar development has been described by several groups. Although human breast tissue is difficult to obtain and study, extrapolating the results of murine models, such as the one described, to the human remains problematic. 


\section{Methods}

At five weeks, female wild type (WT) and PRKO mice received pituitary isografts in order to induce a high incidence of mammary tumors with a short latency period. The hormonal environment generated by the isografts includes high levels of prolactin and serum concentrations of estrogen and progesterone that approximate late pregnancy, and induce pregnancy-like development of the WT, but not PRKO, mammary gland. At eight weeks, the mice were administered $1 \mathrm{mg}$ weekly of the carcinogen 7,12-dimethylbenz(a)anthracene (DMBA) for three consecutive weeks. The control group, who received no pituitary isografts, were administered $1 \mathrm{mg}$ weekly of DMBA for six consecutive weeks.

\section{Results}

In DMBA-treated pituitary-isografted mice, a reduction was observed in the mammary tumor incidence in PRKO mice as compared with isogenic WT mice. Mammary tumors developed in $12(60 \%)$ of 20 WT mice but only 3 (15\%) of 20 PRKO mice by 44 weeks after DMBA treatment. With no pituitary isograft, mammary tumors were observed in $4(20 \%)$ of 20 WT mice and 4 (20\%) of 20 PRKO mice up to 47 weeks. When the carcinogen was administered, the proliferative index of the pituitarystimulated WT mammary gland was four-fold higher than similarly treated PRKO glands.

\section{Discussion}

This study indicates a specific role of the PR (distinct from the estrogen receptor) as a mediator for intracellular signaling pathways that are essential for the initiation of the majority of murine mammary tumors induced by DMBA. The data strongly support a role of progesterone in a murine model of carcinogen-induced mammary gland tumorigenesis. These studies may further our understanding of breast cancer etiology and have implications for the routine use of progestins.

\section{References}


1. Lydon JP, Ge G, Kittrell FS, Medina D, O'Malley BW: Murine mammary gland carcinogenesis is critically dependent on progesterone receptor function. Cancer Res. 1999, 59: 4276-4284.

This PDF file was created after publication. 